\title{
HAMBATAN DALAM PROSES PENANAMAN NASIONALISME PADA MAHASISWA DI KAWASAN
}

\author{
Imaniah Kusma Rahayu, Giri Indra Kharisma
}

Indonesian Language and Literature Education Department, Universitas Timor

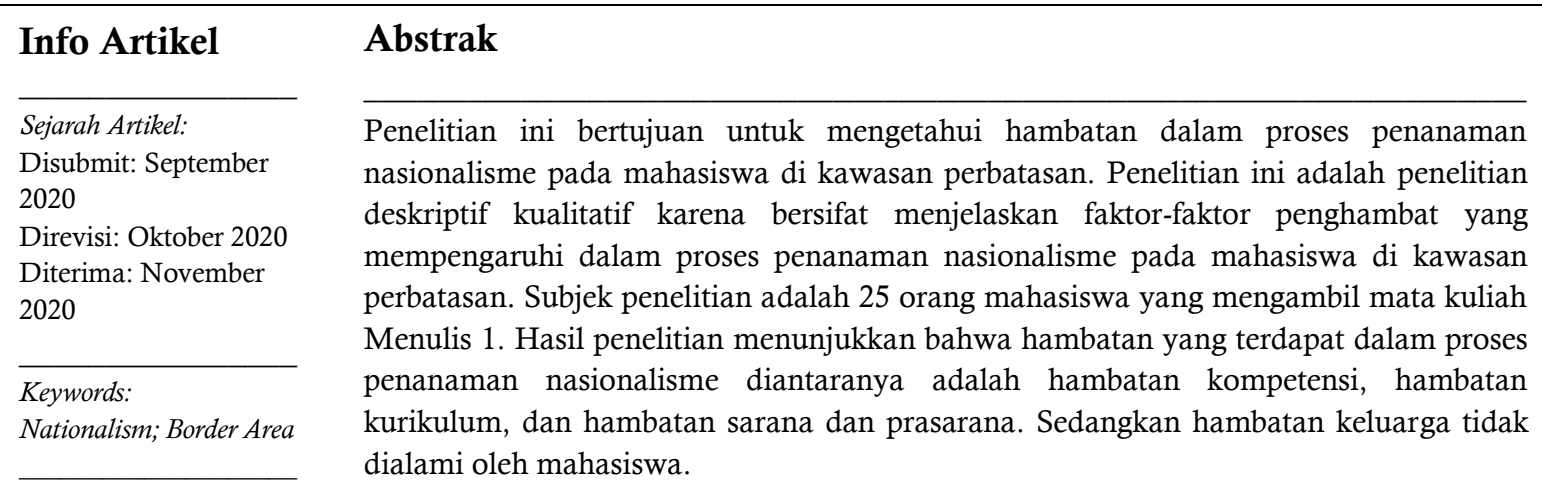

\begin{abstract}
This study aims to determine the obstacles in the process of planting nationalism among students in border areas. This research is a qualitative descriptive study because it explains the inhibiting factors that influence the process of cultivating nationalism among students in border areas. The research subjects were 25 students who took the Writing 1 course. The results showed that the obstacles in the process of planting nationalism were competency barriers, curriculum obstacles, and infrastructure and facilities obstacles. Meanwhile, students do not experience family barriers.
\end{abstract}

(C) 2020 Universitas Negeri Semarang

\footnotetext{
Alamat korespondensi:

Prodi Pendidikan Bahasa dan Sastra Indonesia

Universitas Timor
}

ISSN 2252-7133

E-ISSN 2548-4648

E-mail: niah.ima76@gmail.com 


\section{PENDAHULUAN}

Nasionalisme secara konseptual memiliki makna yang beragam. Ada yang mnegartikan nasionalisme sebagai 1) kulturnation dan staatnation; 2) loyalitas (etnis dan nasional) dan keinginan menegakkan negara; 3) identitas budaya dan bahasa, dan sebagainya (Dewi, 2008). Aman (2011: 40) Nasionalisme merupakan semangat, kesadaran, dan kesetiaan bahwa suatu bangsa itu adalah suatu keluarga dan atas dasar sebagai suatu keluarga bangsa, dibentuklah negara. Nasionalisme merupakan hal yang penting bagi bangsa Indonesia. Sebab, bangsa Indonesia lahir dari semangat nasionalisme.

Begitu pentingnya nilai-nilai nasionalisme, sehingga nasionalisme terusmenerus ditanamkan pada seluruh komponen bangsa. Nilai-nilai nasionalisme yang perlu ditanamkan antara lain 1) Menjaga dan melindungi negara, 2) Sikap rela berkorban/patriotisme, 3) Indonesia bersatu, 4) Melestarikan budaya Indonesia, 5) Cinta Tanah Air, 6) Bangga berbangsa Indonesia, dan 7) Menjunjung tinggi nilai kemanusiaan (Agustarini dalam Nurhayati, 2013:7). Penanaman nilai-nilai nasionalisme diharapkan dapat menjadi semangat untuk tetap menjaga persatuan dan kesatuan.

Nilai-nilai nasionalisme dapat ditumbuhkan melalui berbagai cara. Salah satunya adalah melalui proses pembelajaran baik di sekolah maupun di tingkat perguruan tinggi. Nilai-nilai nasionalisme dapat diintegrasikan pada proses pembelajaran.

Fenomena yang terjadi sekarang di masyarakat adalah lunturnya nilai-nilai nasionalisme di kalangan masyarakat. Berbagai faktor menjadi penyebab lunturnya nilai-nilai nasionalisme salah satunya dalah pengaruh dari pihak luar. Budaya-budaya barat yang masuk ke Indonesia begitu cepat diserap oleh setiap lapisan masyarakat (Octavian, 2014: 70-71). Budaya tersebut dapat berupa perilaku dan penampilan gaya bahasa, pola pikir dan mode pakaian. Tidak semua budaya tersebut bersifat negatif dan memiliki dampak yang buruk. Tetapi, hal itu dapat menjadikan sifat konsumtif terhadap apa yang berasal dari luar dan secara tidak langsung dapat mempengaruhi sikap nasionalisme masyrakat khususnya generasi muda. Selain itu, adanya globalisasi juga akan memunculkan citra global dengan budaya global yang langsung menentang budaya lokal (Naisbit dalam Yasa 2011). Hal tersebut rawan terjadi pada masyarakat di kawasan perbatsan karena berbatasan langsung dengan negara lain.

Kawasan perbatasan adalah kawasan yang secara geografis maupun administratif berbatasan langsung dengan suatu negara. Tidak hanya masalah nasionalisme, berbagai persoalan juga dialami oleh masyarakat di kawasan perbatasan. Kemiskinan, sarana dan prasarana pendidikan yang belum baik, kekurangan air bersih, dll. Tantangan inilah yang harus dihadapi masyarakat di kawasan perbatasan.

Masyarakat di kawasan perbatasan tak terkecuali mahasiswa memerlukan perhatian khusus agar tetap memiliki nasionalisme. Oleh karena itu diperlukan pendidikan yang mampu menanamkan sikap nasionalisme. Hal ini diperlukan agar semangat generasi muda dalam memiliki jiwa nasionalisme tetap terjaga.

Penanaman nilai-nilai nasionalisme tentunya tidaklah mudah. Berbagai hambatan terutama dalam bidang pendidikan dapat menjadi penyebab sulitnya penanaman nilai-nilai nasionalisme. Hambatan tersebut antara lain: 1) hambatan kompetensi, 2) hambatan kurikulum, 3) hambatan sarana dan prasarana, dan 4) hambatan lingkungan. Dengan mengetahui hambatan-hambatan yang dapat mengganggu proses penanaman nilai-nilai nasionalisme diharapkan hambatan-hambatan tersebut dapat diminimalisir.

Tujuan dari penelitian ini adalah mendeskripsikan hambatan-hambatan dalam proses pelaksanaan nilai-nilai nasionalisme pada mahasiswa di kawasan perbatasan.

\section{METODE}

Penelitian ini adalah penelitian deskriptif kualitatif. Subjek dalam penelitian ini adalah mahasiswa Prodi Pendidikan Bahasa dan Sastra Indonesia yang berjumlah 25 orang. Teknik pengumpulan data dalam penelitian meliputi observasi, wawancara, dan angket. Data yang dikumpulkan dalam penelitian berupa informasi 
tentang hambatan dalam proses penanaman nasionalisme pada mahasiswa di kawasan perbatasan.

Instrumen penelitian meliputi lembar observasi, pedoman wawancara, dan angket. Wawancara dan angket digunakan untuk memperoleh data mengenai faktor yang menghambat proses penanaman nasionalisme pada mahasiswa di kawasan perbatasan. Observasi dilakukan untuk melakukan pengamatan terhadap sikap nasionalisme pada mahasiswa. Analisis data dilakukan menurut Miles and Huberman (1992:15-19) dimulai dari pengumpulan data, reduksi data, penyajian data, dan penarikan simpulan dan verifikasi.

\section{PEMBAHASAN}

\section{Hambatan kompetensi}

Pendidik (guru/dosen) bertugas untuk mengajarkan materi pelajaran dan juga bertugas untuk menanamkan nilai-nilai karakter. Salah satu nilai karakter yang perlu ditanamkan adalah sikap nasionalisme. Dosen berperan penting dalam proses penanaman nilai nasionalisme. Pengintegrasian nilai nasionalisme ke dalam proses pembelajaran dapat dilakukan untuk menanamkan nilai nasionalisme tersebut. Dalam implementasinya, kompetensi diperlukan dalam proses penanaman nilai nasionalisme tersebut.

Kompetensi guru dapat dibagi menjadi tiga bidang, yaitu kompetensi bidang kognitif, kompetensi bidang sikap, dan kompetensi perilaku/performance (Sudjana, 2002: 18). Kompetensi bidang kognitif berhubungan dengan kemampuan dalam bidang intelektual seperti, menguasai materi dan diintegrasikan dengan penanaman nilai-nilai nasionalisme. Kompetensi bidang sikap berupa dimiliknya sikap yang baik sehingga dapat menjadi teladan. Sikap yang dimaksud adalah sikap yang menunjukkan nilainilai nasionalisme. Kompetensi perilaku/ performance berupa kemampuan untuk mengajar, menyusun perencanaan dalam mengajar, dll. Apabila kompetensi tersebut tidak dimiliki maka dapat menghambat proses pelaksanaan nilai-nilai nasionalisme. Hambatan kompetensi terdiri atas: 1) Penyusunan RPS yang mengintegrasikan nilai nasionalisme dan 2) Penggunaan media pembelajaran.

\section{Menyusun RPS yang mengintegrasikan nilai nasionalisme}

Berdasarkan angket yang diberikan kepada mahasiswa, 18 orang mahasiswa menyatakan bahwa dosen mengalami hambatan dalam menyusun RPS yang mengintegrasikan nilai-nilai nasionalisme dan 7 orang menyatakan bahwa dosen tidak mengalami hambatan dalam menyusun RPS yang mengintegrasikan nilai nasionalisme didalamnya. Penyusunan RPS yang terintegrasi dengan nilai-nilai nasionalisme masih belum maksimal. Hal ini juga terlihat dalam dokumen RPS yang disusun oleh para dosen. Belum maksimalnya penyusunan RPS yang terintegrasi dengan nilai-nilai nasionalisme disebabkan karena dalam penyusunan RPS terfokus pada materi yang akan diajarkan bukan pada nilai-nilai nasionalismenya. Belum maksimalnya RPS yang mengintegrasikan dengan nilai-nilai nasionalisme mneyebabkan dalam pelaksanaannyapun belum maksimal. Kendala lain adalah karakter dari mahasiswa yang berbeda-beda.

Berdasarkan hasil observasi, angket, dan dokumentasi RPS dapat disimpulkan bahwa penyusunan RPS yang mengintegrasikan nilainilai nasionalisme belum maksimal. Sedangkan dalam pelaksanaannya RPS yang mengintegrasikan nilai nasionalisme juga belum maksimal karena penyusunan RPS itu sendiri belum maksimal. Selain itu, karakter mahasiswa yang berbeda juga turut mempengaruhi pelaksanaan nilai-nilai nasionalisme tersebut.

\section{Penggunaan media pembelajaran}

Media Pembelajaran diperlukan untuk mendukung pelaksanaan kegiatan pembelajaran menurut hasil angket diperoleh hasil bahwa dalam kegiatan pembelajaran sudah digunakan media pembelajaran. Akan tetapi karena keterbatasan sarana dan prasarana penggunaan media belum optimal. Berdasarkan data angket, 24 mahasiswa menyatakan bahwa media pembelajaran telah digunakan. Media pembelajaran yang digunakan biasanya berupa laptop dan LCD. Dari hasil observasi, ada beberapa ruang yang tidak terpasang LCD 
sehingga hal ini membuat penggunaan media pembelajaran pun tidak maksimal. Ruang yang tidak memiliki LCD adalah ruang-ruang seperti aula, student center. Ruang tersebut biasanya digunakan untuk proses perkuliahan jika jumlah mahasiswa yang mengikuti kuliah dalam jumlah besar. Ruang-ruang tersebut juga digunakan karena keterbatasan ruang.

Berdasarkan hasil observasi dan angket, dapat disimpulkan bahwa penggunaan media pembelajaran sudah digunakan akan tetapi penggunaannya belum maksimal. Dalam artian, semua dosen sudah menggunakan media pembelajaran, akan tetapi karena keterbatasan sarana maka ada yang tidak menggunakan.

\section{Hambatan kurikulum}

Kurikulum merupakan suatu perangkat yang akan membantu proses kegiatan pendidikan yang akan berlangsung di sekolah. Kurikulum dengan pendidikan adalah dua hal yang sangat erat kaitannya dan tidak dapat dipisahkan. Menurut UU No. 20 tahun 2003 bab 1 pasal 1 ayat 19 "kurikulum adalah seperangkat rencana dan pengaturan mengenai tujuan, isi dan bahan pelajaran serta cara yang digunakan sebagai pedoman penyelenggaraan kegiatan pembelajaran untuk mencapai tujuan pendidikan tertentu". Apabila dalam penyelenggaraan kegiatan pendidikan tersebut terdapat kurikulum yang baik. maka tujuan yang akan dicapain dari pendidikan tersebut akan terwujud. Sedangkan apabila dalam penyelenggaraan pendidikan tersebut terdapat kurikulum yang buruk, maka tujuan yang diinginkanpun akan sulit tercapai.

Dari hasil angket, ditemukan data bahwa 11 orang mahasiswa menyatakan bahwa beban kurikulum terlalu berat dan 14 orang menyatakan tidak terlalu berat. Beban kurikulum yang terlalu berat, juga dissampaikan mahasiswa dalam kegiatan wawancara. Hal ini sesuai dengan pernyataan yang diungkapkan "ZA", salah satu mahasiswa yang menyatakan bahwa "Mata kuliah yang harus kita pelajari masih asing. Banyak istilah-istilah asing yang belum diketahui. Materi yang diajarkan kadang terlalu sulit. Dosen hanya memberi tugas dan memberikan penjelasan sedikit. Tugas juga terlalu banyak".
Hasil wawancara di atas juga diperkuat dengan pengamatan peneliti pada saat observasi ketika bimbingan dan konsultasi KHS dan KRS. Dalam kegiatan konsultasi, banyak mahasiswa tidak mengikuti mata kuliah yang seharusnya terjadwal dikarenakan IP nya tidak mencapai hasil yang diinginkan. Sehingga setiap semesternya, mereka terpaksa mengambil mata kuliah yang beleum diambil pada semester berikutnya. Hal ini menyebabkan mahasiswa tidak lulus tepat waktu. Selain itu, kegiatan ekstrakurikuler juga masih terbatas.

Materi yang diajarkan terkadang juga tidak kontekstual dengan keadaan mereka yang berada di kawasan perbatasan. Hal ini menyebabkan mereka kesulitan dalam memahami materi. Daya serap mahasiswa yang berbeda juga turut membuat mereka kesulitan dalam memahami materi. Nurdin (2005: 38) mengungkapkan bahwa beban kurikulum yang dipikul oleh guru sangat padat bahkan terjadi "pemaksaan" dalam dua hal, yaitu alokasi waktu yang terbatas dan daya serap siswa terhadap apa yang disampaikan oleh guru. Hal ini juga terjadi pada mahasiswa. Tingkat daya serap mahasiswa yang berbeda turut mempengaruhi pemahaman mereka terhadap materi yang diajarkan.

Berdasarkan hasil analisis data angket, wawancara, dan observasi, beban kurikulum yang dirasa terlalu berat disebabkan karena pemilihan materi yang tidak kontekstual dengan keadaan mereka. Tingkat daya serap mahasiswa tinggi juga mempengaruhi. Hamalik (2009:20-21) menyatakan bahwa pada dasarnya betapapun baiknya suatu kurikulum, berhasil atau tidaknya akan sangat bergantung pada tindakan-tindakan guru di sekolah dalam melaksanakan kurikulum. Sehingga penilaian baik atau buruknya kurikulum hanya dapat dilihat dari proses pelaksanaannya dalam kegiatan pembelajaran, karena yang melaksanakan suatu kurikulum adalah guru. Hal yang sama pun terjadi di tingkat perguruan tinggi karena yang melaksanakan suatu kurikulum di tingkat perguruan tinggi adalah dosen.

\section{Hambatan sarana dan prasarana}

Sarana dan prasarana pendidikan merupakan hal yang sangat menunjang atas 
tercapainya suatu tujuan pendidikan. Menurut Bafadal (2003: 2) sarana pendidikan adalah semua perangkat peralatan, bahan dan perabot yang secara langsung digunakan dalam proses pendidikan di sekolah. Sedangkan prasarana pendidikan adalah semua perangkat kelengkapan dasar yang secara tidak langsung menunjang pelaksanaan proses pendidikan di sekolah. Adapun menurut Suharsimi Arikunto (1993: 8182) sarana pendidikan merupakan sarana penunjang bagi proses belajar-mengajar dan segala sesuatu yang dapat memudahkan pelaksanaan kegiatan tertentu. Sehinggga guru dan siswa dapat terbantu dalam proses pembelajaran. Sarana prasarana merupakan hal yang sangat pokok dalam proses pendidikan.

Berdasarkan hasil observasi, hambatan dalam sarana dan prasarana juga masih dialami. Hal ini terlihat dari sarana dan prasarana yang tersedia belum lengkap. Seperti masih terbatasanya ruang perkuliahan, belum adanya ruang perpustakaan prodi, laboratorium bahasa. Media pembelajaran yang belum lengkap seperti belum adanya speaker dalam setiap ruangan, mic dan alat-alat ekstra yang tidak lengkap. Hal itu mengakibatkan tidak terlaksana dengan baik kegiatan-kegiatan penunjang yang berhubungan dengan penanaman nilai-nilai nasionlisme seperti upacara bendera. Arikunto (1993: 81-82) mengatakan bahwa sarana pendidikan merupakan sarana penunjang bagi proses belajar mengajar dan segala sesuatu yang dapat memudahkan pelaksanaan kegiatan tertentu. Sarana prasarana merupakan hal yang sangat pokok dalam proses pendidikan. Hal ini juga didukung oleh pernyataan GEB dalam pernyataannya "Masih ada ruangan yang tidak ada LCD nya. Selain itu, terkadang kami juga harus jalan jauh karena tidak kuliah di ruangan milik kampus lain".

Dari pembahasan tersebut dapat disimpulkan bahwa sarana dan prasarana yang tersedia belum lengkap. Hal ini tampak dari terbatasnya ruang untuk perkuliahan sehingga harus meminjam ruangan kampus lain, belum adanya ruang perpustakaan prodi, laboratorium bahasa, dll.

\section{Hambatan lingkungan}

Pembelajaran pada hakikatnya adalah proses interaksi antara siswa dengan lingkungannya (Mulyasa 2003: 100). Banyak faktor berpengaruh dalam interaksi tersebut. Baik faktor internal yang berasal dari individu tersebut maupun faktor eksternal yang datang dari lingkungan. Antara pembelajaran dan lingkungan, memiliki kiatan yang sangat erat.

Berdasarkan hasil angket dan wawancara, dapat disimpulkan bahwa mahasiswa tidak mengalami hambatan lingkungan keluarga dalam pelaksanaan nilai-nilai nasionalisme. Hal itu terlihat dari banyaknya orang tua yang sudah memberi contoh karakter-karakter baik selama di rumah. Dalyono (2009: 130) menyatakan bahwa lingkungan keluarga berpengaruh besar terhadap pertumbuhan dan perkembangan anak.

Dari pembahasan tersebut, dapat disimpulkan bahwa mahasiswa tidak mengalami hambatan lingkungan keluarga. Orang tua di rumah sudah memberi contoh karakter-karakter baik.

\section{SIMPULAN}

Berdasarkan hasil penelitian mengenai hambatan dalam proses penanaman nasionalisme pada mahasiswa di kawasan perbatasan, dapat disimpulkan sebagai berikut. 1) Hambatan kompetensi yang dialami karena belum maksimalnya dosen dalam membuat RPS yang mengintegrasikan dengan nilai nasionalisme sehingga dalam pelaksanaannya juga belum maksimal. 2) Hambatan kurikulum yang dialami adalah pemilihan materi yang tidak kontekstual, tidak sesuai dengan keadaan yang berada di kawasan perbatasan sehingga dirasa terlalu berat. 3) Hambatan sarana dan prasana diantaranya, terbatasanya ruang perkuliahan, ruang perpustakaan, ruang laboratorium, dll 4) Hambatan keluarga tidak dialami oelh para mahasiswa karena para orang tua sudah memberikan teladan dalam hal karakter-karakter baik. Hal ini terlihat dari sarana dan prasarana yang tersedia belum lengkap. Hambatanhambatan tersebut baik secara langsung maupun tidak langsung dapat mempengaruhi proses pelaksanaan penanaman nasionalisme terhadap mahasiswa di kawasan perbatasan. 


\section{DAFTAR PUSTAKA}

Aman. 2011. Model Evaluasi Pembelajaran Sejarah. Yogyakarta: Ombak.

Arikunto, Suharsimi. 1993. Organisasi dan Administrasi Pendidikan Teknologi dan Kejuruan. Jakarta: PT Raja Grafindo.

Bafadal, Ibrahim. Manajemen Perlengkapan Sekolah Teori dan Aplikaisnya. Jakarta: Bumi Aksara.

Dalyono, M. 2009. Psikologi Pendidikan. Jakarta: Rineka Cipta.

Dewi, Ita Mutiara. 2008. Nasionalisme dan Kebangkitan dalam Teropong. Mozaik Vol. 3 No 3, Juli 2008 ISSN 1907-6126

Hamalik, Oemar. 2009. Pendidikan Guru: Berdasarkan Pendekatan Kompetensi. Jakarta: PT Bumi Aksara.

Miles, M. B. and Huberman, M. 2012. Analisis Data Kualitatif. Terj. Tjejep Rohidi. Jakarta: UI Press.

Mulyasa. 2003. Kepala Sekolah Profesional. Bandung: PT Remaja Rosdakarya.

Nurdin, Muhamad. 2005. Pendidikan yang Menyebalkan. Yogyakarta: Arr-Ruzz.
Nurhayati, Yanti. 2013. Pengaruh Upacara Bendera Terhadap Sikap Nasionalisme di SMP N 14 Bandung. Bandung: Universitas Pendidikan Indonesia.

Octavian, Wendy Anugrah. 2014. Peranan Penggunaan Media Film Pada Proses Pembelajaran PKn dalam Mengembangkan Sikap Nasionalusme Siswa (Studi Deskriptif Analisis Pada Siswa Kelas $\mathrm{X}$ SMA Negeri 11 Palembang). JPIS, Jurnal Pendidikan Ilmu Sosial. Vol. 23 No 1. Juni 2014.

Sudjana, Nana. 2002. Dasar-dasar Proses Belajar Mengajar. Bandung: Sinar Baru Algesindo.

Yasa, I Made Sumartha. 2011. Pengembangan Alat Ukur Sikap Nasionalisme Pada Siswa Rsbi Sma Negeri 1 Gianyar Tahun Pelajaran. Jurnal Penelitian Pascasarjana Undiksha Vol 2, No 2 Tahun 2012. [Tersedia Online].

http://pasca.undiksha.ac.id/ejournal/ind ex.php/jurnal_ep/article/download/376/ 168. Diakses Pada Tanggal 4 November 2020 Pukul 19:14 WIB. 